Research Article

\title{
Study on Microseismic Monitoring, Early Warning, and Comprehensive Prevention of a Rock Burst under Complex Conditions
}

\author{
Ke Ding, ${ }^{1}$ Lianguo Wang, ${ }^{1}$ Mei Yu $\mathbb{D},{ }^{1,2}$ Wenmiao Wang, ${ }^{3}$ and Bo Ren ${ }^{1}$ \\ ${ }^{1}$ State Key Laboratory for Geomechanics and Deep Underground Engineering, China University of Mining and Technology, \\ Xuzhou, Jiangsu 221116, China \\ ${ }^{2}$ School of Mechanics and Civil Engineering, China University of Mining and Technology, Xuzhou, Jiangsu 221116, China \\ ${ }^{3}$ School of Mines, China University of Mining and Technology, Xuzhou, Jiangsu 221116, China
}

Correspondence should be addressed to Mei Yu; meiyu@cumt.edu.cn

Received 18 June 2020; Revised 13 July 2020; Accepted 8 August 2020; Published 19 September 2020

Academic Editor: Bangyou Jiang

Copyright (C) 2020 Ke Ding et al. This is an open access article distributed under the Creative Commons Attribution License, which permits unrestricted use, distribution, and reproduction in any medium, provided the original work is properly cited.

\begin{abstract}
Rock bursts in coal mines are usually unpredictable. In view of this problem, the energy-frequency relationship and spatial distribution characteristics of microseismic events during the mining of 5305 working face in Xinhe Coal Mine under complex geological conditions were analyzed in this study. Besides, the law and precursors of rock burst occurrence in this working face were discussed. The following research results were obtained. Before the rock burst occurred in 5305 working face, the energy and frequency of microseismic events vary in the following order: "peak-drop-rise-rock burst." The analysis on spatial characteristics of microseismic events suggests that microseismic events were mainly concentrated at the boundary between the roof and the coal seam or at the hard roof near the coal seam within 0-160 $\mathrm{m}$ in front of the working face, and most of the events lay on the goaf side. Moreover, the energy and frequency of microseismic events both decrease in the above region before the rock burst occurred. This "microseismic event absence" phenomenon can be regarded as one of the precursors of rock burst occurrence. In addition, a multilevel antiburst scheme was proposed for the complex conditions: (1) to adopt large-diameter boreholes pressure relief technology and key layer high-level pressure relief technology for adjusting the stress distribution in the surrounding rock of crossheading in front of the working face and dissipating elastic strain energy; (2) to determine the advance speed to be $1.5 \mathrm{~m} / \mathrm{d}$ for reducing the mining disturbance; (3) to adopt full-section reinforced support of the roadway for enhancing the antiburst capacity of surrounding rock. After the implementation of this scheme, the energy and frequency of microseismic events monitored on-site changed gently, and 5305 working face was safely recovered to the stop line position. The scheme boasts a remarkable rock burst prevention and control effect.
\end{abstract}

\section{Introduction}

A rock burst, a serious coal and rock dynamic instability disaster in coal mining, usually features suddenness, destructiveness, and complicated mechanism. As mining extends deeper, the frequency and destructiveness of rock burst disasters increase day by day $[1,2]$, which has been confirmed by domestic and foreign reports on such disasters in recent years. For example, (i) on August 6 and August 16, 2007, two consecutive major rock burst accidents (mining depth $683 \mathrm{~m}$, maximum magnitude $3.9 \mathrm{M}$ ) occurred in
Crandall Canyon Coal Mine in Utah, USA, causing 9 deaths and 6 injuries; (ii) in 2008, the "6.5" rock burst accident occurring in Qianqiu Coal Mine in Henan Province, China, resulted in an instantaneous uplift of nearly $100 \mathrm{~m}$ of the roadway. Consequently, among the 20 trapped miners who were working in this section, 9 were killed and 11 were injured; (iii) in 2018, the "10 20 " major rock burst accident occurring in Longyun Coal Mine, Shandong Province, China, led to 21 deaths and severe destruction of nearly $100 \mathrm{~m}$ roadway. Rock bursts have become one of the most serious disasters facing mining in many countries, and how 
to effectively predict rock bursts has become an urgent problem that restricts the safe production in mines [3-6].

At present, the technologies of rock burst monitoring and early warning mainly include the microseismic method, the electromagnetic radiation method, the stress online method, the acoustic emission method, and the drilling cutting method [7-12], among which the microseismic method boasts the most promising application prospect [13]. Shen et al. [14] studied the monitoring results of displacement, stress, and seismicity in the roadway roof of a longwall face in Australia during mining-induced failure, concluding that seismicity could better reveal the roof failure process compared with displacement and stress. Furthermore, they investigated the precursor information of seismicity during roof failure. Brady and Leighton [15] researched on seismicity anomaly prior to a rock burst event in a hard rock mine and found that seismicity kept intensifying with the progress of mining and fell suddenly before the roof strata broke. Legge and Spottiswoode [16] believed that the B-value variation in the Gutenberg-Richter formula was greatly influenced by blasting, but it could also reflect the regional geometric changes in rock fracturing around the working face. In fact, these changes would exert a certain effect on the rock burst risk. Xie and Pariseau [17] held that the distribution of microseismic events had fractal characteristics, and the fractal dimension during rock burst evolution could be directly measured by the distribution of microseismic events. When a rock burst was about to happen, the microseismic events became rather concentrated so that the fractal dimension decreased. Hence, they considered that the distribution of microseismic events with the minimum fractal dimension could be regarded as a credible precursor of rock burst. Les Niak and Isakow [18] assessed the rock burst risk according to the spatial and temporal clustering characteristics of microseismic events. With the aid of a plastic expansion model, Cianciara et al. [19] described the brittle characteristics of coal rock fracturing after mining and disclosed the equidistant failure areas appearing in a layered medium. These areas were related to the release of highenergy vibrations whose nonuniformity could be used for rock burst prediction.

In the aspect of prevention and control of rock burst, $\mathrm{He}$ et al. [20] proposed the prevention and control method of rock burst in steeply inclined coal seam. Tan et al. [21] discussed the prevention and control technology of rock burst in hard roof and floor coal seam of coal mine. Yang et al. [22] focused on the analysis and prevention of rock burst under deep and complex geological conditions, and many scientific researchers took various measures to prevent rock burst under different geological conditions [23-25].

In summary, the judgment of coal mine rock burst risk is mainly based on seismological methods at home and abroad currently. Some Chinese scholars also studied the structural characteristics of overburden migration in coal mines with rock burst risk by means of microseismic fracture space imaging, and the obtained research results ensured the safety of coal mine production to a certain extent [20-30].
However, due to considerable differences in the mining and geological conditions, these methods are not applicable to all the working faces [31]. In this study, considering complex conditions such as hard roof, hard coal seam, asymmetric mining, and many roadways (hereafter referred to as the "two-hard" complex conditions) in 5305 working face of Xinhe Coal Mine, the spatial distribution evolution of microseismic events was investigated based on the information acquired by the microseismic monitoring system. Meanwhile, a multilevel antiburst scheme was proposed for the "two-hard" complex conditions. The research results provide a valuable reference for rock burst monitoring in other working faces.

\section{Overview of the Working Face and Characteristics of the Rock Burst}

2.1. Overview of Xinhe Coal Mine. Xinhe Coal Mine is located in Jiaxiang County, Jining City, China. Its main coal seam is No. 3 coal seam whose coal thickness ranges from $8.85 \mathrm{~m}$ to $10.6 \mathrm{~m}$ and averages $9.42 \mathrm{~m}$. The coal seam, buried at the depth of $970-1010 \mathrm{~m}$, is primarily mined by adopting the method of strike longwall retreating comprehensive mechanized caving mining. A thick (thickness 7-9 m) layered integral sandstone mass generally exists in the roof, as presented in Figure 1. It has been identified that No. 3 coal seam possesses a strong rock burst tendency and its roof has a weak rock burst tendency. The 5305 working face belongs to a typical example subjected to the "two-hard" complex conditions.

2.2. Mining Conditions of the Working Face. In Xinhe Coal Mine, 5305 working face is located in the northeast of 530 mining area. It borders on the middle lane of 5304 working face to the north, 5304 working face, 5301 goaf and 5302 goaf to the west, the belt gateway of 5302 working face to the south, and the belt concentrated lane to the east. As shown in Figure 1, 5305 working face whose one side is close to the goaf is mined asymmetrically; besides, many roadways are arranged in the working face. In short, the mining conditions are rather complex.

2.3. Rock Burst Occurrence. At 12:11:29 on July 24, 2018, when 5305 working face was mined for $193.7 \mathrm{~m}$, a rock burst event (source energy $4 \times 10^{4} \mathrm{~J}$ ) occurred at the entrance of crossheading. The specific position was $127 \mathrm{~m}$ in front of the advancing mining position and $7 \mathrm{~m}$ within the production side of the gateway. Three coal bursts occurred continuously on-site, among which the third one was the loudest. The occurrence of coal bursts was accompanied by the production of a storm and abundant coal dust. The rock burst event resulted in different degrees of damage to the roadway in a range of about $2 \mathrm{~m} \times 5 \mathrm{~m}$ within the production side, including partial roof collapse, serious roadway contraction, anchor bolt pull-out, and anchor cable cut-off in local areas. The on-site damage situation is exhibited in Figure 2. 


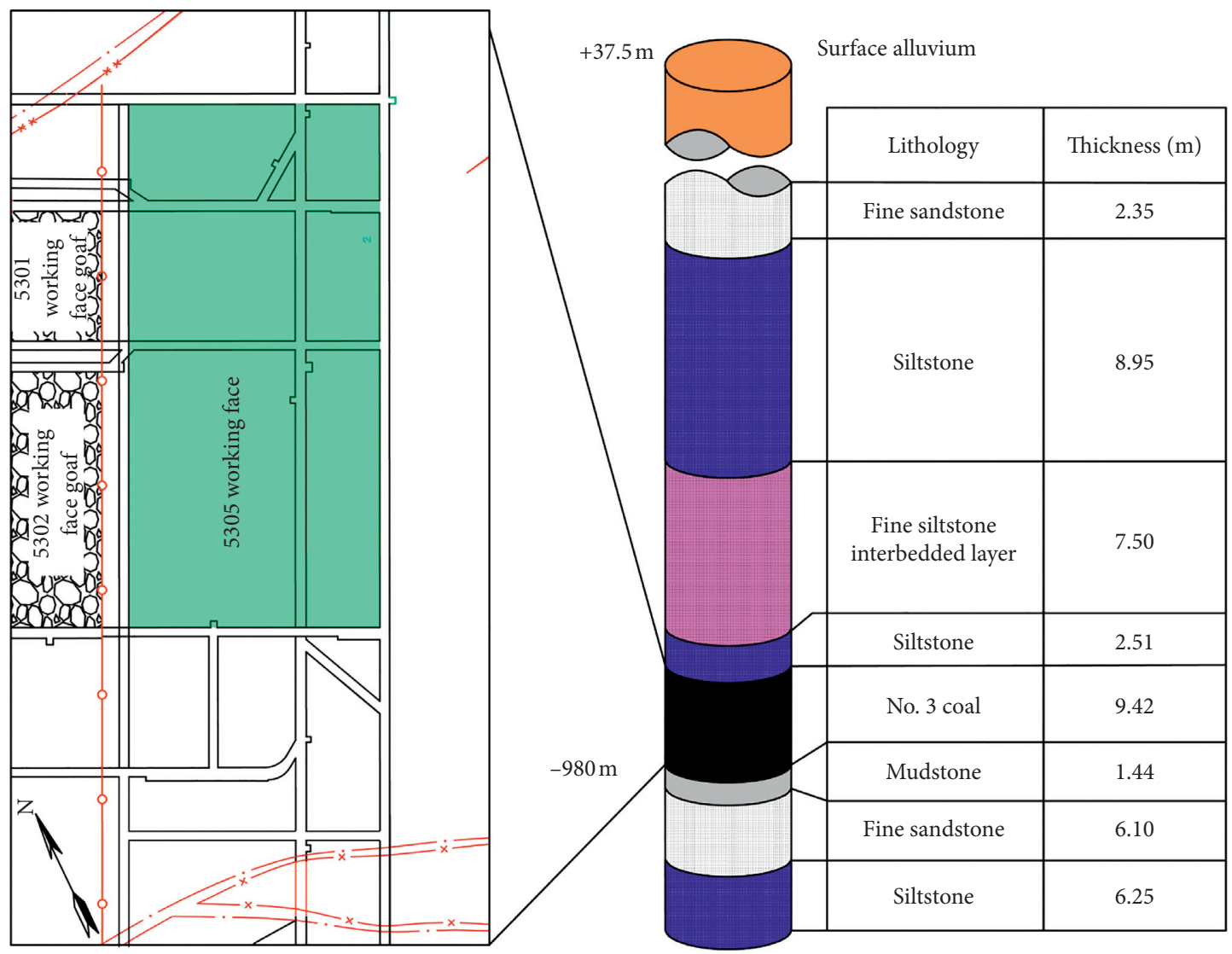

FIgURE 1: Layout of 5305 working face.

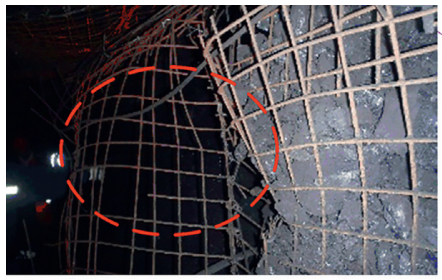

Metal mesh bulging on the roadway side

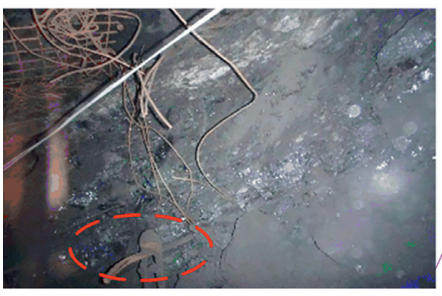

Bolt damage in the roadway

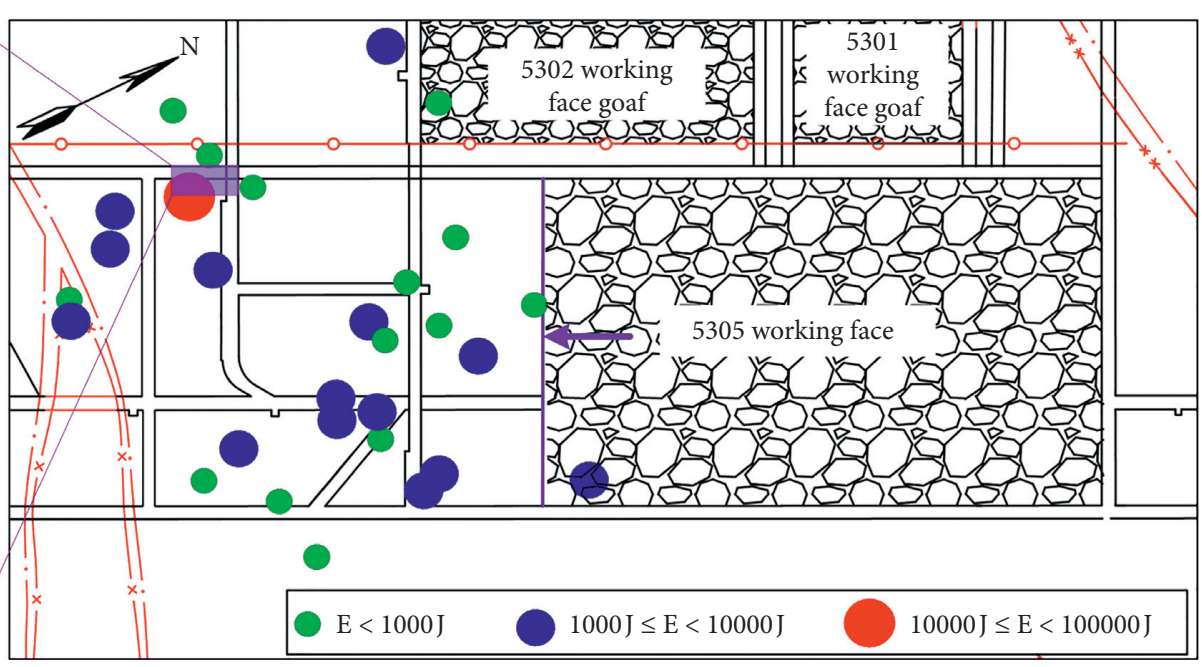

FIgURE 2: Situation of on-site damage induced by the rock burst.

\section{Spatial and Temporal Characteristics of Microseismic Events}

3.1. Temporal Characteristics of Microseismic Events and Rock Burst Precursors. Rock bursts and microseismic events belong to two different concepts. Rock bursts occur in three stages: burst initiation, burst energy transfer, and burst manifestation, while microseismic events are the release of energy without any destructive manifestation in the mining space. Microseismic events can serve as the dynamic load source for rock burst start-up [32, 33]. Thus, the occurrence of a rock burst can be predicted by exploring the law of microseismic events prior to the rock burst and uncovering the relationship between 
the law of microseismic event occurrence and the rock burst.

The single-day maximum energy, accumulated energy, and vibration frequency variations of microseismic events in 5305 working face from June 30 to July 31, 2018, are disclosed in Figure 3. An overall analysis on the variations in the $30 \mathrm{~d}$ indicates that prior to the appearance of the " $7 \bullet 24$ " rock burst, few microseismic events occurred, releasing little energy (mostly less than $1.0 \times 10^{4} \mathrm{~J}$ ). This period is called the energy accumulation period. Around the appearance of the " $7 \bullet 24$ " rock burst, there was a high-incidence period (duration $7 \mathrm{~d}$ ) in which microseismic events occurred frequently, releasing vast energy every day. This period is called the active period of microseismic events or the energy release period. Moreover, according to the analysis on the variations in the $4 \mathrm{~d}$ before the appearance of the " $7 \bullet 24$ " rock burst, the accumulated energy and the vibration frequency both witnessed a peak and then started to drop; after dropping to a certain level, the two data began to go upward simultaneously; the rock burst occurred within $1 \mathrm{~h}$ afterwards. In the whole process, the accumulated energy and the vibration frequency vary in the following order: "peak-drop-rise-rock burst."

3.2. Spatial Characteristics of Microseismic Events and Rock Burst Precursors. Predicting the rock burst merely through temporal characteristics such as energy and frequency can hardly satisfy the engineering requirements. It is also feasible to seek rock burst precursors through spatial characteristics of microseismic events. The overall plane distribution of microseismic events during the appearance of the " $7 \bullet 24$ " rock burst is exhibited in Figure 4 where the dots represent the positions of microseismic sources. As can be observed from Figure 4, microseismic events, which occurred infrequently, were mainly concentrated $0-160 \mathrm{~m}$ in front of the working face as the working face advances. With respect to vertical distribution, microseismic events were mainly concentrated at the boundary between the roof and the coal seam or at the hard roof near the coal seam (Figure 5).

To exploring the spatial evolution of major microseismic events before the rock burst appearance, the spatial distribution of microseismic events from July 19 to July 23 was sorted out (Figure 6). The following phenomena can be observed from the monitoring results: On July 19 (Figure 6(a)), microseismic events were mainly concentrated at the boundary between the roof and the coal seam or at the hard roof near the coal seam that were $0-160 \mathrm{~m}$ ahead of the working face. Most of them were located near the roadway and fault area. On July 20 (Figure 6(b)), microseismic events, with a greater number and a wider distribution range, were mainly concentrated $0-160 \mathrm{~m}$ ahead of the working face. Besides, they moved from the roof to the coal seam. On July 21 and July 22 (Figures 6(c) and 6(d)), microseismic events, with a reduced number and a shrunk distribution range, tended to be concentrated towards the crossheading in front of the working face. This variation suggests that stress became increasingly concentrated and rock strength got reduced near this region, which can be regarded as an indication of the upcoming " $7 \bullet 24$ " rock burst. Meanwhile, it can also be seen that fractures had begun to accumulate at the strong burst source on July 24. On July 23 (Figure 6(e)), microseismic events continued to decrease and became distributed in a further reduced range. The events with a higher energy level were further concentrated near the crossheading, with almost no events distributed $0-40 \mathrm{~m}$ ahead of the working face.

The plane distribution of microseismic events in the period July 19-23 demonstrates that microseismic events, which were of a relatively large magnitude, were mainly concentrated near the crossheading $40-160 \mathrm{~m}$ in front of the working face with the advancement of the working face. With respect to vertical distribution, microseismic events were mainly concentrated at the boundary between the roof and the coal seam or at the hard roof near the coal seam. After microseismic events occurred frequently in the working face on July 20, they decrease in terms of both frequency and energy for 3 consecutive days, exhibiting an evident "microseismic event absence" phenomenon. This phenomenon indicated that microseismic events with great magnitudes were likely to occur to make up for the long-term lack of average magnitude. According to Figures 4 and 5, the burst event did occur in the roof area near the crossheading in front of the working face. Therefore, the hard coal seam, the roof, and the crossheading in the working face significantly impacted the burst event occurrence. It can be considered that the burst event occurring on July 24 was promoted by energy accumulation under "two-hard" complex conditions and induced by roof breakage disturbance.

Although some spatial and temporal distribution characteristics of microseismic energy and frequency before the rock burst have been revealed in the above analysis, it remains difficult to accurately predict the rock burst merely based on these characteristics. This is because the prediction of rock burst event generally faces the problems of undeterminable energy or frequency thresholds and varying precursors, which greatly reduces the accuracy of prediction of rock burst occurrence probability and time. In short, many aspects of coal mine microseismic signal characteristics under complex conditions still worth in-depth study and discussion. An analysis combined with more microseismic monitoring data of mines under similar mining conditions is essential. Only by clarifying the correlation among the characteristics of microseismic events, the law of precursors, the law of hard roof breakage, and the spatial structure characteristics of the stope can the study provide a basis for comprehensively predicting rock burst events under complex conditions.

\section{Multilevel Rock Burst Prevention and Control Measures}

As can be known from the above analysis and field measurement, around the rock burst appearance in 5305 working face, microseismic events were mainly concentrated near the crossheading 40-160 $\mathrm{m}$ in front of the working face, specifically, at the boundary between the roof and the coal seam or at the hard roof near the coal seam. Therefore, the ideas of multilevel rock burst prevention and control under 


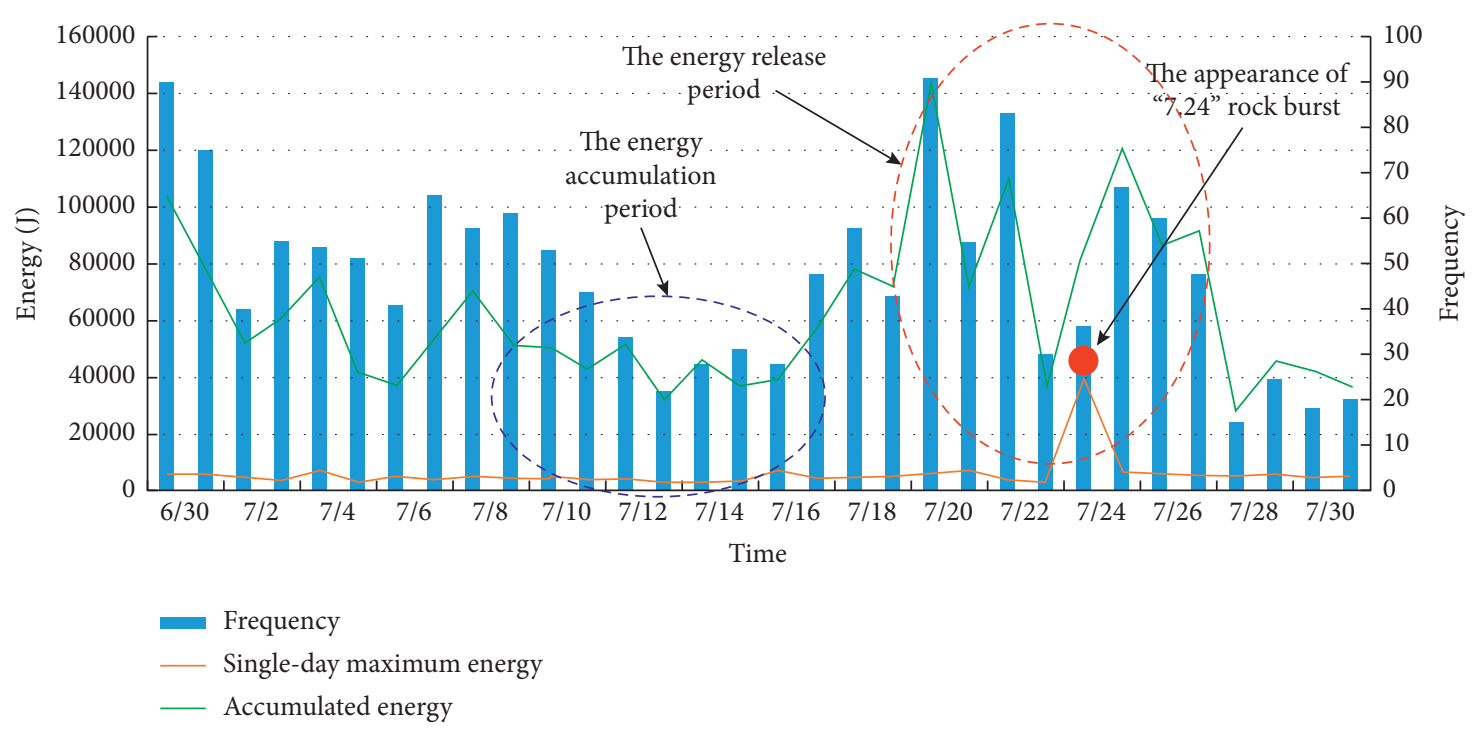

FIgURE 3: Diagram of microseismic energy and vibration frequency variations in 5305 working face.

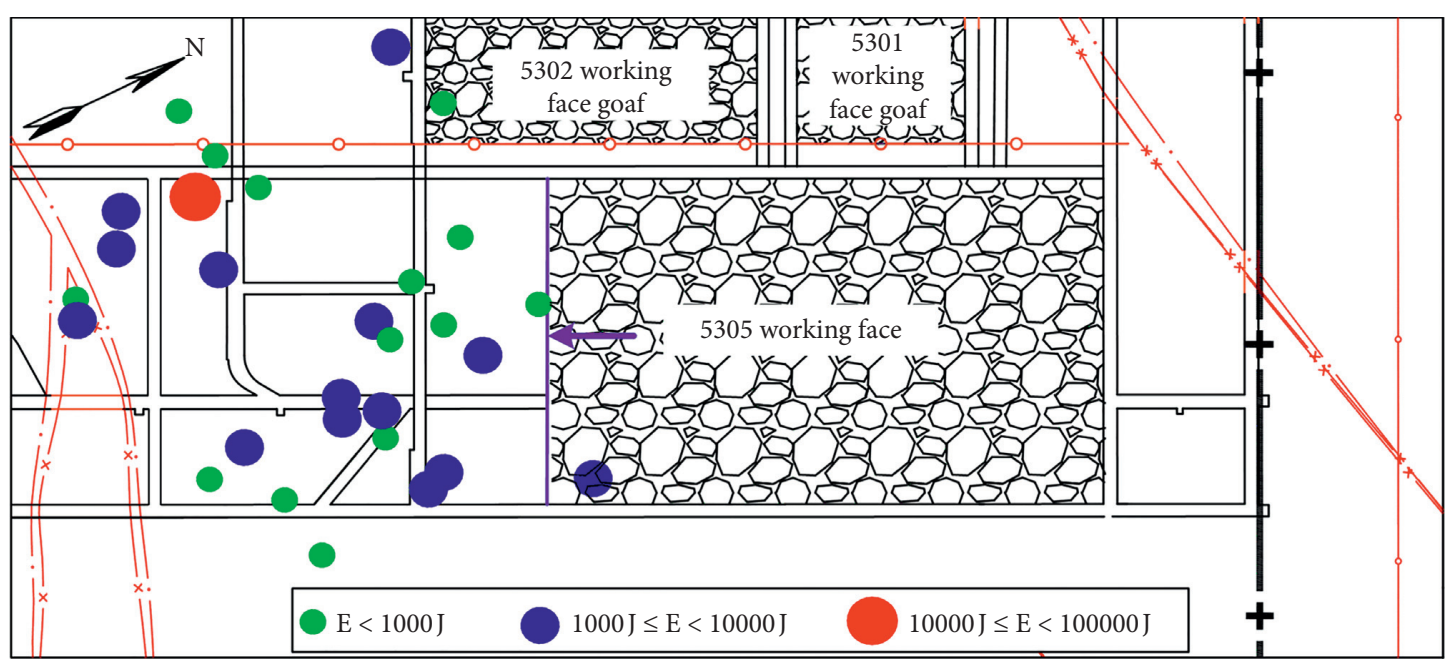

FIgURE 4: Plane distribution of microseismic events during the rock burst appearance.

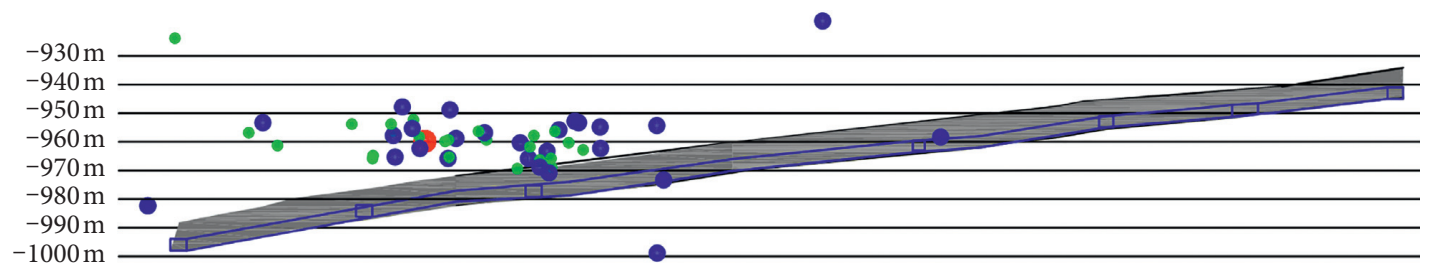

FIGURE 5: Vertical distribution of microseismic events during the rock burst appearance.

complex conditions include three aspects: (1) to adopt large-diameter boreholes pressure relief technology and key layer high-level pressure relief technology for adjusting the stress distribution in the surrounding rock of crossheading in front of the working face and weakening the influence of "two-hard" complex conditions on the rock burst appearance in the working face; (2) to adopt fullsection reinforcement of the roadway for promoting the support strength of surrounding rock and enhancing the antiburst capacity; (3) to determine a reasonable advance speed for reducing the mining disturbance and releasing coal rock energy evenly. 


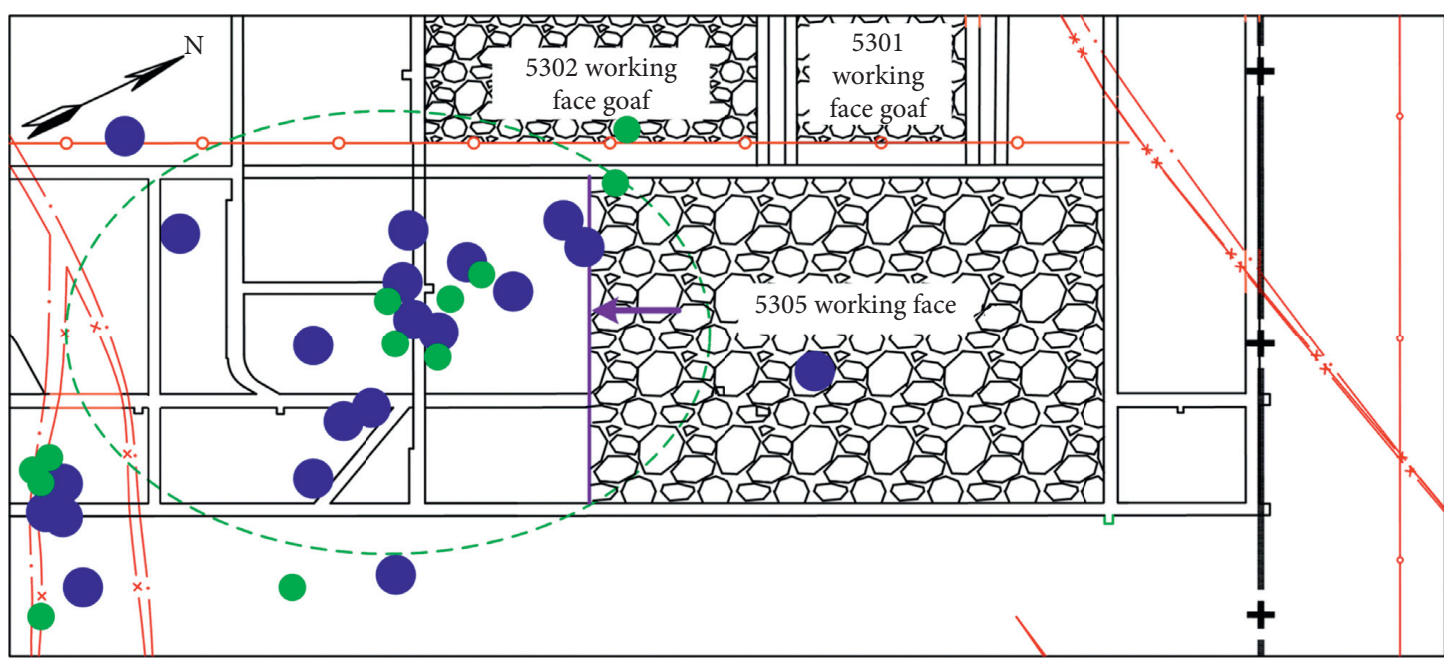

$-930 \mathrm{~m}$

$-940 \mathrm{~m}$

$-950 \mathrm{~m}$

$-960 \mathrm{~m}$

$-970 \mathrm{~m}$

$-980 \mathrm{~m}$

$-990 \mathrm{~m}$

$-1000 \mathrm{~m}$

(a)
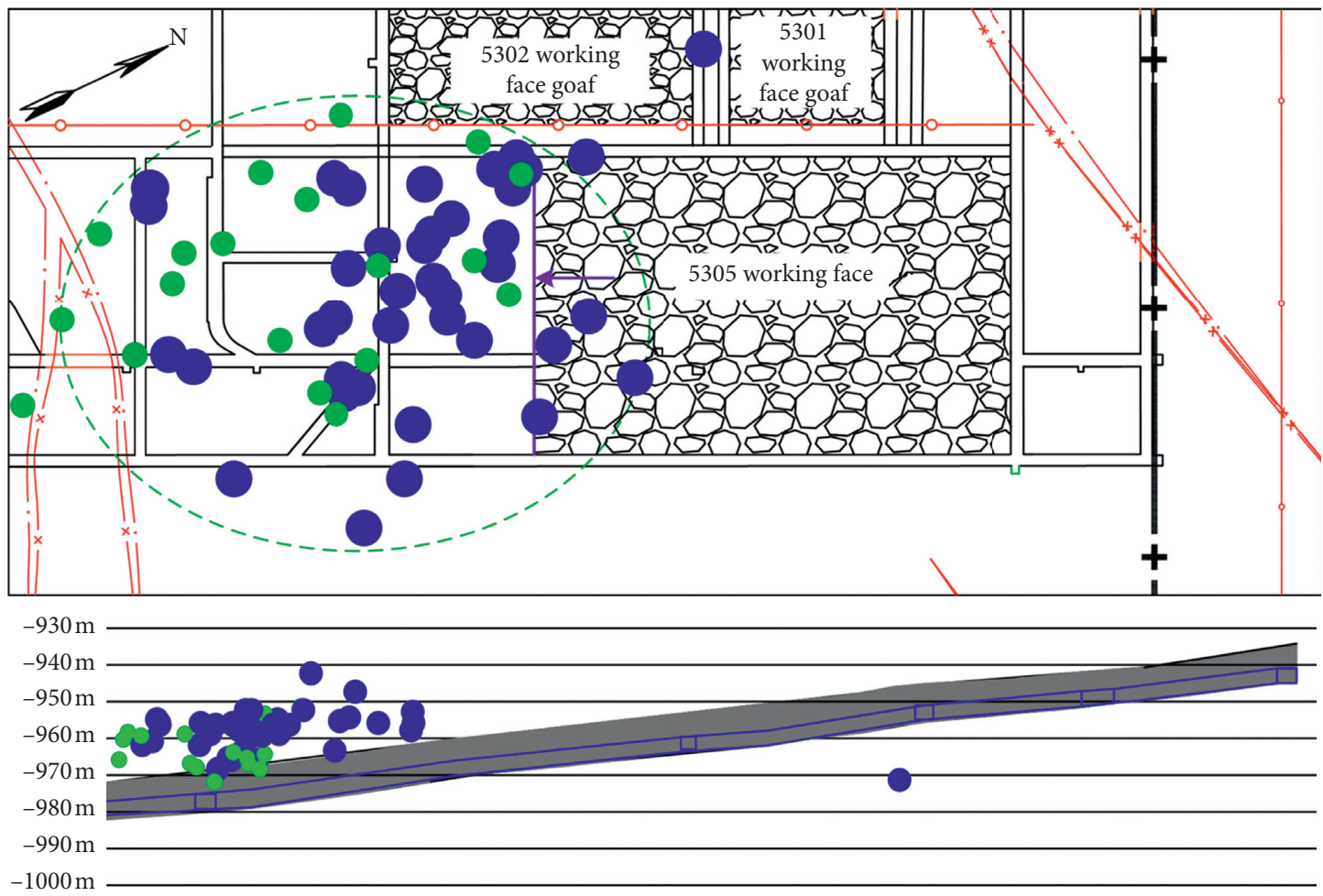

(b)

Figure 6: Continued. 

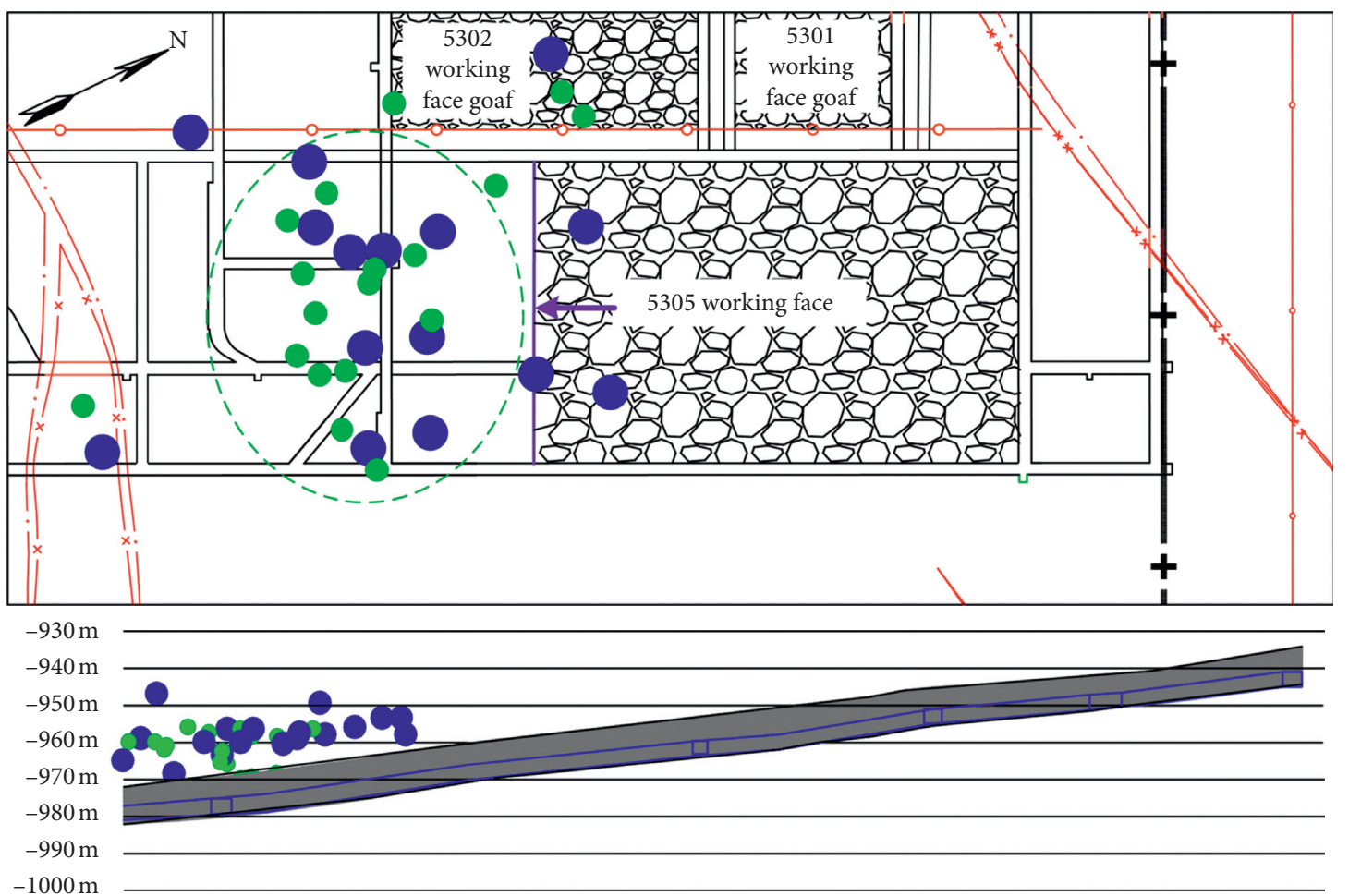

(c)

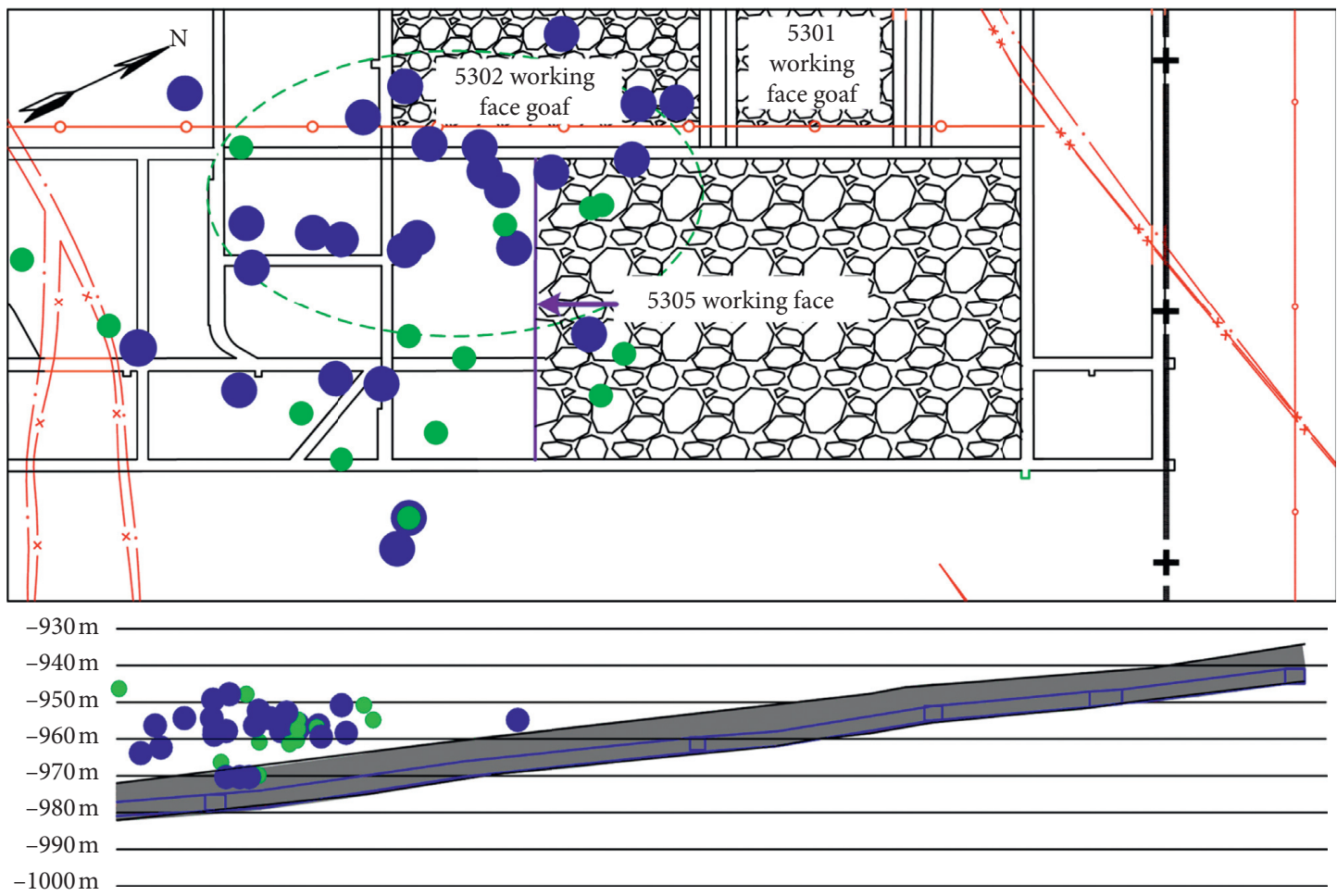

(d)

Figure 6: Continued. 


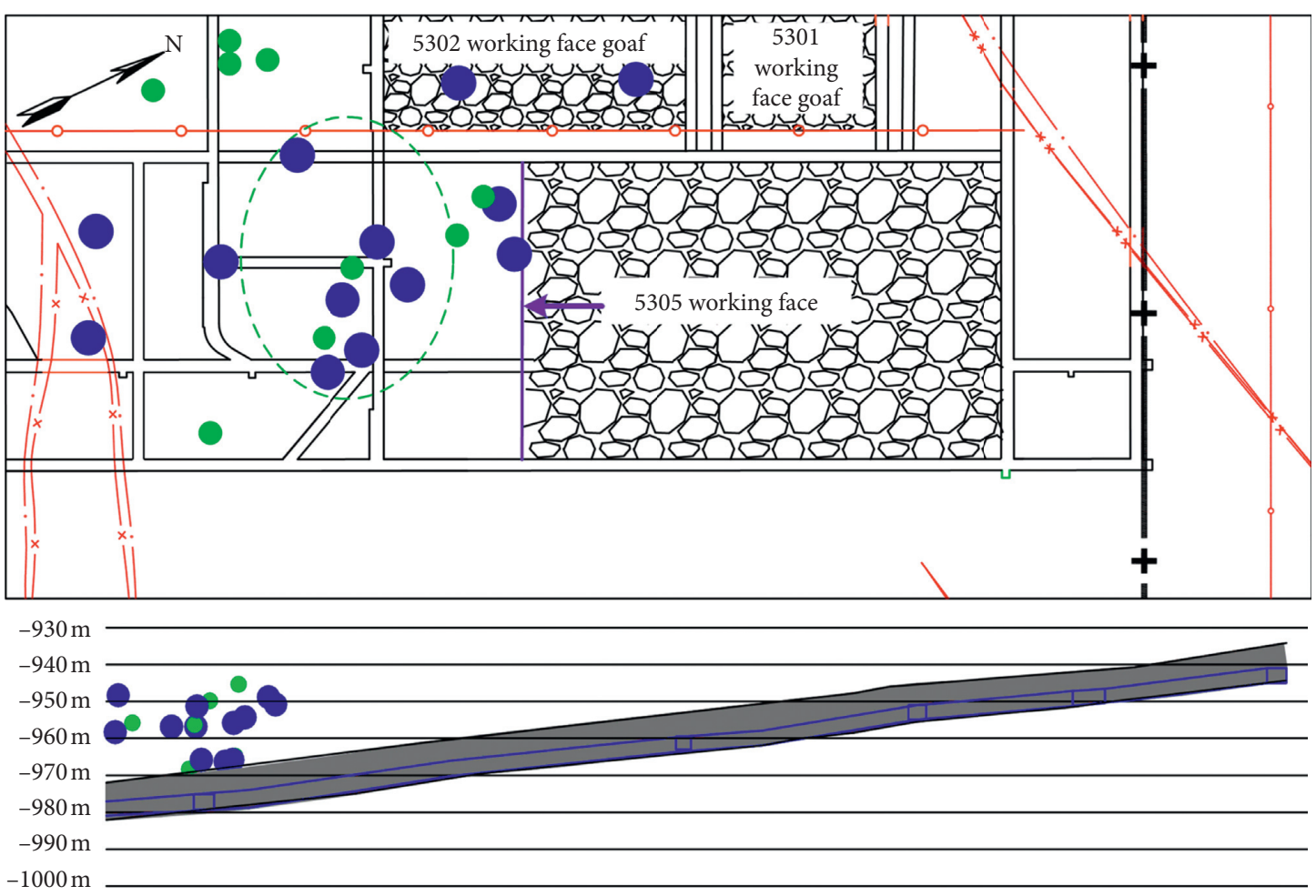

(e)

FIGURE 6: Spatial distribution evolution of microseismic events before the rock burst appearance (July 19-23). (a) July 19, (b) July 20, (c) July 21, (d) July 22, and (e) July 23.

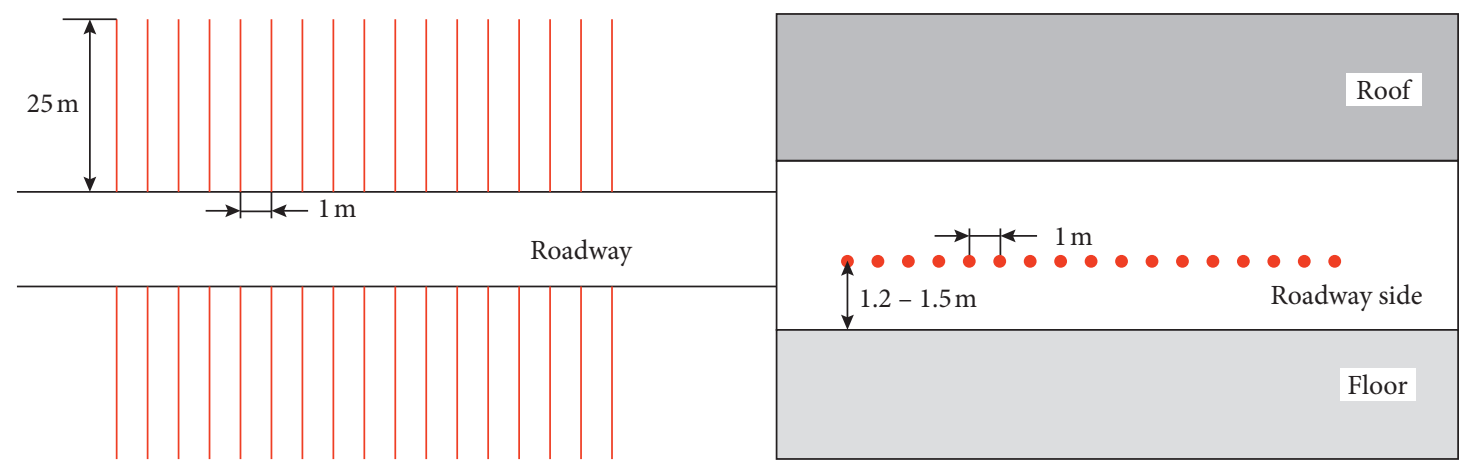

Large-diameter boreholes for pressure relief

FiguRe 7: Layout of large-diameter boreholes for pressure relief.

4.1. Pressure Relief through Large-Diameter Boreholes on the Roadway Sides. Pressure relief through large-diameter boreholes can transfer high stress to the deep, reduce the elastic modulus, and increase the deformation capacity of coal, thus altering energy accumulation conditions of a coal seam and weakening the coal seam burst tendency. Given the microseismic monitoring results of 5305 working face, large-diameter boreholes for pressure relief were constructed on both roadway sides of the crossheading to reduce or eliminate the stress concentration in deep coal. The boreholes were arranged in the hope of ensuring a low-stress state of the transportation roadway. The depth, diameter, and spacing of the boreholes were $25 \mathrm{~m}, 150 \mathrm{~mm}$, and $1 \mathrm{~m}$, respectively. The layout of these boreholes is illustrated in Figure 7.

4.2. Pressure Relief through Deep-Hole Blasting Presplitting at the Roof. There is a layer of hard siltstone with a thickness of about $8.95 \mathrm{~m}$ about $10 \mathrm{~m}$ above No. 3 coal seam roof. This layer is the key layer for inducing the rock burst in 5305 working face. According to the microseismic monitoring results, microseismic events were mainly concentrated at the boundary between the roof and the coal seam or at the 


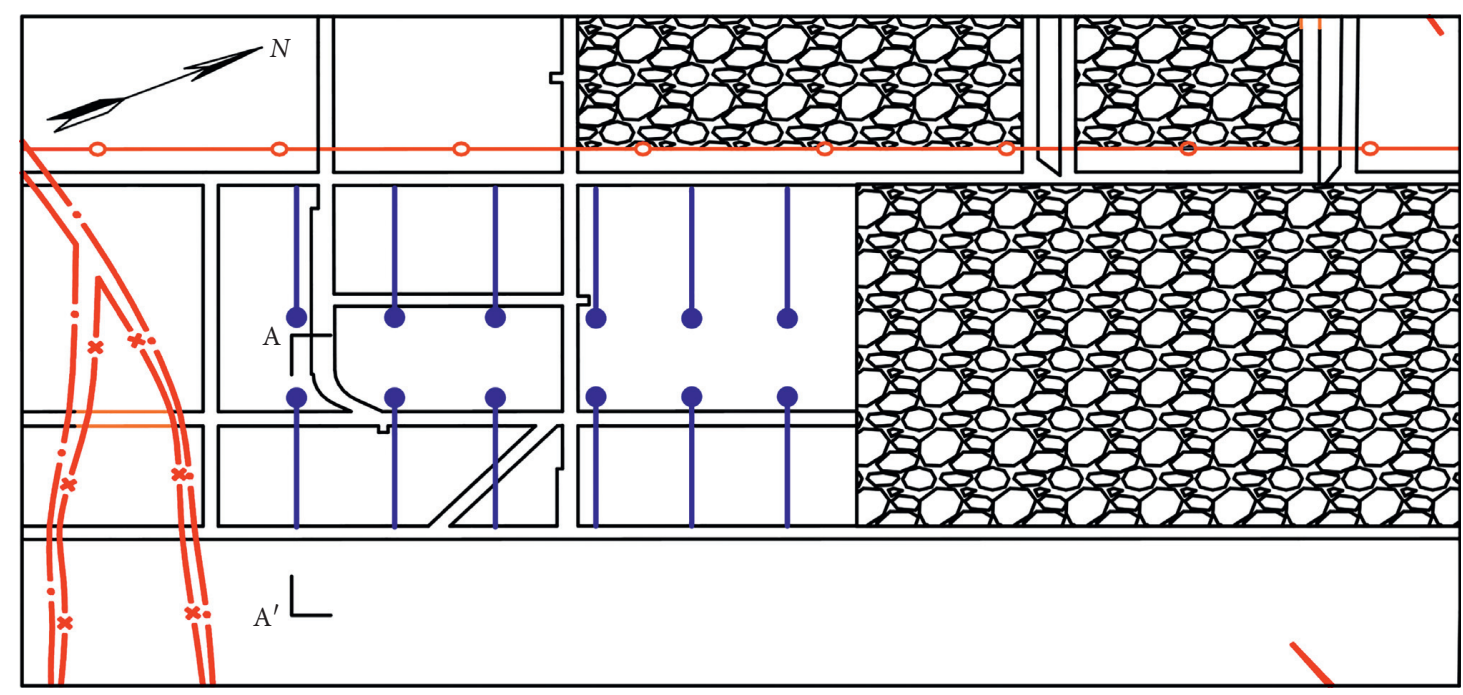

(a)

A-A':

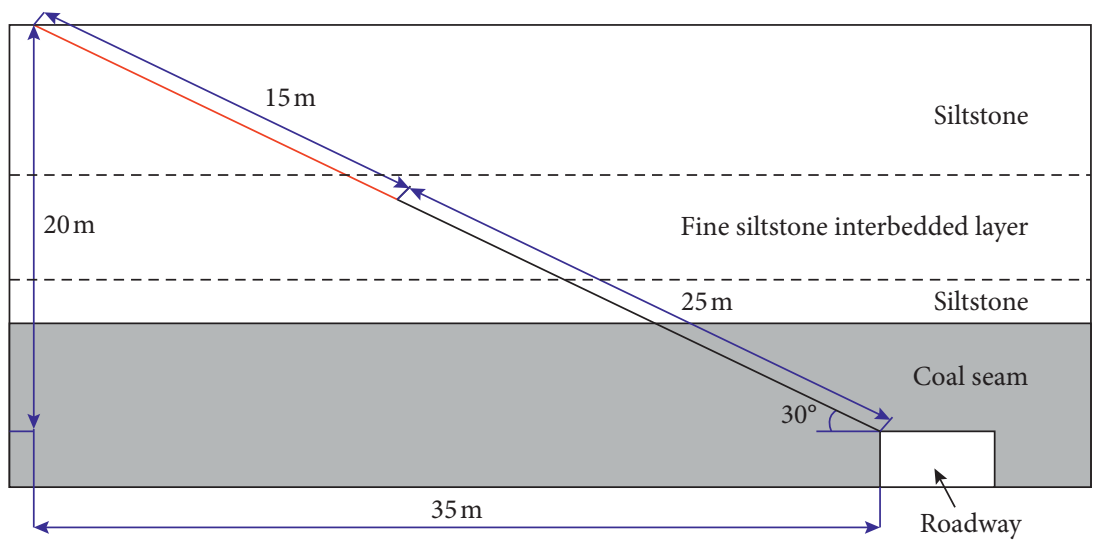

(b)

Figure 8: Layout of blasting boreholes at the roof. (a) Boreholes layout plan. (b) A-A' borehole profile.

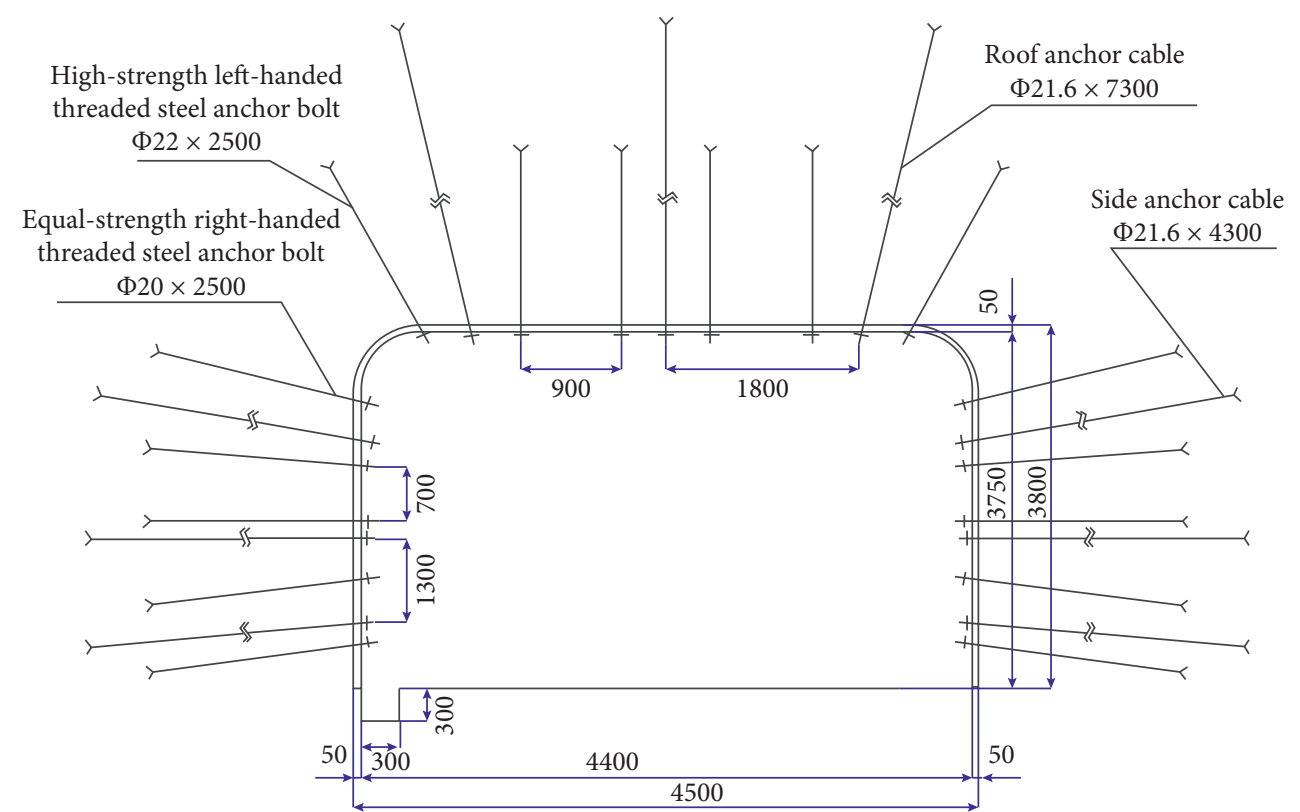

FIGURE 9: Design of reinforced support in the roadway. 


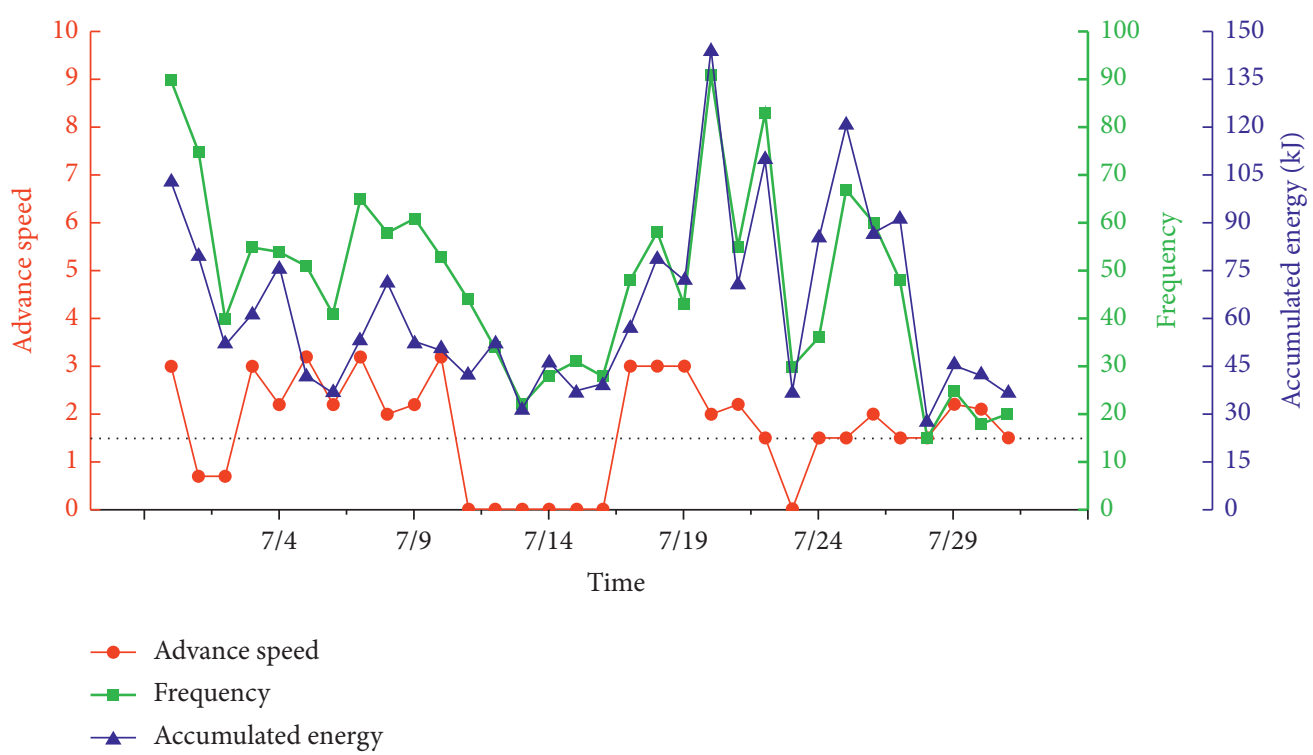

FIGURE 10: Relationship between the microseismic activity and the advance speed.

hard roof near the coal seam. Thus, in the subsequent mining process, the hard roof was subjected to deep-hole blasting presplitting to decrease the natural caving area of the roof and lower the intensity of energy released by roof breakage. Blasting presplitting boreholes were designed at the roof of two gateways in the working face. Parameters of the boreholes are as follows: spacing between boreholes $30 \mathrm{~m}$, borehole depth $40 \mathrm{~m}$, angle between the boreholes and the coal seam $15^{\circ}$, charge length $15 \mathrm{~m}$, and borehole sealing length $25 \mathrm{~m}$. The layout of the boreholes is given in Figure 8.

4.3. Full-Section Reinforced Support of the Roadway. In order to improve the support strength of the roadway, enhance the overall antiburst capacity of the surrounding rock, and limit rock bursts, the following work was done: The areas where the rock burst occurred and where the roadway was severely broken and deformed were repaired and reinforced; the cross section was expanded to the designed size; and the original support was reinforced. The layout of the support is displayed in Figure 9. The specific parameters are as follows:

(1) The roof was supported through high-strength lefthanded threaded steel anchor bolts (diameter $22 \mathrm{~mm}$, length $2.5 \mathrm{~m}$, and row spacing $0.9 \mathrm{~m} \times 1.0 \mathrm{~m}$ ). The support was reinforced through the combination of anchor cables (length of $7.3 \mathrm{~m}$, row spacing $1.8 \mathrm{~m} \times 1.3 \mathrm{~m}$ ) and $\mathrm{T}$-shaped steel belts (length $4 \mathrm{~m}$, spacing $1.3 \mathrm{~m}$ arranged along the roadway).

(2) The two sides were supported through equalstrength right-handed threaded steel anchor bolts (diameter $20 \mathrm{~mm}$, length $2.5 \mathrm{~m}$, and row spacing $0.7 \mathrm{~m} \times 2.0 \mathrm{~m}$ ). The support was reinforced through anchor cables (length of $4.3 \mathrm{~m}$, row spacing $1.2 \mathrm{~m} \times 2.0 \mathrm{~m}$ ). Both the anchor bolts and the anchor cables were used in combination with $\mathrm{W}$-shaped steel belts (length $1.6 \mathrm{~m}$ ).

4.4. Determination of a Reasonable Advance Speed. The microseismic activity increases with the increase of the advance speed of the working face. Rock burst events tend to occur if the advance speed is too high or when the production of the working face is just stopped and resumed. The relationship between the microseismic activity and the advance speed of 5305 working face is presented in Figure 10. The microseismic events are of low energy and frequency when the advance speed $v \leq 1.5 \mathrm{~m} / \mathrm{d}$, while they are intense and of increased energy and frequency when the advance speed $v>1.5 \mathrm{~m} / \mathrm{d}$. Thereby, the subsequent advance speed is determined to be $1.5 \mathrm{~m} / \mathrm{d}$.

\section{Conclusions}

(1) The analysis on temporal characteristics of microseismic events in 5305 working face suggests that the microseismic accumulated energy and the vibration frequency vary in the following order: "peak-drop-rise-rock burst."

(2) The analysis on spatial characteristics of microseismic events suggests that microseismic events were mainly concentrated near the crossheading that was $0-160 \mathrm{~m}$ in front of the working face. The burst source was mainly located at the boundary between the roof and the coal seam or at the hard roof near the coal seam.

(3) A multilevel antiburst scheme, namely, "pressure relief of coal rock, full-section reinforced support of the roadway, and determination of a reasonable advance speed," was implemented. After the implementation, no more large-energy microseismic events occurred on-site. The scheme succeeded in ensuring the subsequent safe mining of the working face. 


\section{Data Availability}

The data used to support the findings of this study are included within the article.

\section{Conflicts of Interest}

The authors declare that they have no conflicts of interest regarding the publication of this work.

\section{References}

[1] A. Mazaira and P. Konicek, "Intense rockburst impacts in deep underground construction and their prevention," $\mathrm{Ca}$ nadian Geotechnical Journal, vol. 52, no. 10, pp. 1426-1439, 2015.

[2] T. Li, M. F. Cai, and M. Cai, "A review of mining-induced seismicity in China," International Journal of Rock Mechanics and Mining Sciences, vol. 44, no. 8, pp. 1149-1171, 2007.

[3] D. S. Dreger, S. R. Ford, and W. R. Walter, "Source analysis of the crandall canyon, Utah, mine collapse," Science, vol. 321, no. 5886, p. $217,2008$.

[4] J. C. Pechmann, W. J. Arabasz, K. L. Pankow, R. Burlacu, and M. K. McCarter, "Seismological report on the 6 august 2007 crandall canyon mine collapse in Utah," Seismological Research Letters, vol. 79, no. 5, pp. 620-636, 2008.

[5] G.-F. Wang, S.-Y. Gong, Z.-L. Li, L.-M. Dou, W. Cai, and Y. Mao, "Evolution of stress concentration and energy release before rock bursts: two case studies from Xingan coal mine, Hegang, China," Rock Mechanics and Rock Engineering, vol. 49, no. 8, pp. 3393-3401, 2016.

[6] Y. D. Jiang, Y. S. Pan, F. X. Jiang, and L. M. Dou, "State of the art review on mechanism and prevention of coal bumps in China," Journal of China Coal Society, vol. 39, no. 2, pp. 205-213, 2014, in Chinese.

[7] W. Cao, J.-Q. Shi, G. Si, S. Durucan, and A. Korre, "Numerical modelling of microseismicity associated with longwall coal mining," International Journal of Coal Geology, vol. 193, pp. 30-45, 2018.

[8] C. a. Tang, J. Wang, and J. Zhang, "Preliminary engineering application of microseismic monitoring technique to rockburst prediction in tunneling of Jinping II project," Journal of Rock Mechanics and Geotechnical Engineering, vol. 2, no. 3, pp. 193-208, 2010.

[9] G. Si, S. Durucan, S. Jamnikar et al., "Seismic monitoring and analysis of excessive gas emissions in heterogeneous coal seams," International Journal of Coal Geology, vol. 149, pp. 41-54, 2015.

[10] A. Lurka, "Location of high seismic activity zones and seismic hazard assessment in Zabrze Bielszowice coal mine using passive tomography," Journal of China University of Mining and Technology, vol. 18, no. 2, pp. 177-181, 2008.

[11] H. He, L. Dou, A. Cao, J. Fan, and Y. L. Ding, "Mechanisms of mining seismicity under large scale exploitation with multikey strata," Shock and Vibration, vol. 2015, Article ID 313069, 9 pages, 2015.

[12] B. Sirait, R. K. Wattimena, and N. P. Widodo, "Rockburst prediction of a cut and fill mine by using energy balance and induced stress," Procedia Earth and Planetary Science, vol. 6, pp. 426-434, 2013.

[13] W. Cai, L. M. Dou, Z. L. Li, J. Liu, S. Y. Gong, and J. He, "Micro-seismic multidimensional information identification and spatio-temporal forecasting of rock burst: a case study of Yima Yuejin coal mine, Henan, China," Chinese Journal of
Geophysics-Chinese Edition, vol. 57, no. 8, pp. 2687-2700, 2014.

[14] B. Shen, A. King, and H. Guo, "Displacement, stress and seismicity in roadway roofs during mining-induced failure," International Journal of Rock Mechanics and Mining Sciences, vol. 45, no. 5, pp. 672-688, 2007.

[15] B. T. Brady and F. W. Leighton, "Seismicity anomaly prior to a moderate rock burst: a case study," International Journal of Rock Mechanics and Mining Sciences of Geomechanics Abstracts, vol. 14, no. 3, pp. 127-132, 1977.

[16] N. B. Legge and S. M. Spottiswoode, "Fracturing and microseismicity ahead of a deep gold mine stope in the preremnant and remnant stages of mining," in Proceedings of the ISRM 6thInternational Congress Rock Mechamics Montreal, pp. 1071-1077, Montreal, Canada, August 1987.

[17] H. Xie and W. G. Pariseau, "Fractal character and mechanism of rock bursts," International Journal of Rock Mechanics and Mining Sciences \& Geomechanics Abstracts, vol. 30, no. 4, pp. 343-350, 1993.

[18] A. Les Niak and Z. Isakow, "Space-time clustering of seismic events and hazard assessment in the Zabrze-Bielszowicecoalmine, Poland," International Journal of Rock Mechanics and Mining Sciences, vol. 46, no. 5, pp. 918-928, 2009.

[19] B. Cianciara, H. Marcak, X. H. Tang, and Z. Y. Fei, "Interpretation of geophysical anomaly of potential field by singularity method and filtering method," World Geology, vol. 2, pp. 163-169, 1983, in Chinese.

[20] S. Q. He, D. Z. Song, X. Q. He et al., "Coupled mechanism of compression and prying-induced rock burst in steeply inclined coal seams and principles for its prevention," Tunnelling and Underground Space Technology, vol. 98, Article ID 103327, 2020.

[21] Y. L. Tan, X. S. Liu, B. Shen, Q. H. Gu, and J. G. Ning, "New approaches to testing and evaluating the rockburst risk of coal seam with hard roof and/or floor in coal mines," Geomechanics and Engineering, vol. 14, no. 4, pp. 367-376, 2018.

[22] Z. Yang, C. Liu, H. Zhu, F. Xie, L. Dou, and J. Chen, "Mechanism of rock burst caused by fracture of key strata during irregular working face mining and its prevention methods," International Journal of Mining Science and Technology, vol. 29, no. 6, pp. 889-897, 2019.

[23] D. Y. Fan, X. S. Liu, Y. L. Tan et al., "Roof cutting parameters design for gob-side entry in deep coal mine: a case study," Energies, vol. 12, no. 10, 2019.

[24] Z. Khademian and O. Ugur, "Computational framework for simulating rock burst in shear and compression," International Journal of Rock Mechanics and Mining Sciences, vol. 110, pp. 279-290, 2018.

[25] D. Fan, X. Liu, Y. Tan, L. Yan, S. Song, and J. Ning, “An innovative approach for gob-side entry retaining in deep coal mines: a case study," Energy Science \& Engineering, vol. 7, no. 6, pp. 2321-2335, 2019.

[26] L. W. Zhang, X. Y. Zhang, J. Wu, D. K. Zhao, and H. Fu, "Rockburst prediction model based on comprehensive weight and extension methods and its engineering application," Bulletin of Engineering Geology and The Environment, 2020.

[27] W. Cai, L. Dou, G. Si, A. Cao, J. He, and S. Liu, "A principal component analysis/fuzzy comprehensive evaluation model for coal burst liability assessment," International Journal of Rock Mechanics and Mining Sciences, vol. 81, pp. 62-69, 2016.

[28] L. M. Dou, J. He, A. Y. Cao, S. Y. Gong, and W. Cai, "Rock burst prevention methods based on theory of dynamic and static combined load induced in coal mine," Journal of China Coal Society, vol. 40, pp. 1469-1476, 2015, in Chinese. 
[29] S. J. Chen, Z. W. Du, Z. Zhang, H. W. Zhang, Z. G. Xia, and F. Feng, "Effects of chloride on the early mechanical properties and microstructure of gangue-cemented paste backfill," Construction and Building Materials, vol. 235, 2020.

[30] R. S. Faradonbeh, A. Taheri, L. R. E. Sousa, and M. Karakus, "Rockburst assessment in deep geotechnical conditions using true-triaxial tests and data-driven approaches," International Journal of Rock Mechanics and Mining Sciences, vol. 128, 2020.

[31] N. Hosseini, K. Oraee, K. Shahriar, and K. Goshtasbi, "Passive seismic velocity tomography and geostatistical simulation on longwall ming panel," Archives of Mining Sciences, vol. 57, pp. 57-67, 2012.

[32] N. Hosseini, K. Oraee, K. Shahriar, and K. Goshtasbi, "Studying the stress redistribution around the longwall mining panel using passive seismic velocity tomography and geostatistical estimation," Arabian Journal of Geosciences, vol. 6, no. 5, pp. 1407-1416, 2013.

[33] R. S. Faradonbeh and A. Taheri, "Long-term prediction of rockburst hazard in deep underground openings using three robust data mining techniques," Engineering with Computers, vol. 35, no. 2, pp. 659-675, 2019. 